\title{
From Poverty to Informality? The Social Question in Africa in a Historical Perspective
}

\author{
Andreas Eckert
}

INTRODUCTION

Jan Breman and Marcel van der Linden argue that "the real norm or standard in global capitalism is insecurity, informality or precariousness." If this is the case, then Africa in the twentieth and early twenty-first centuries could be seen as a model case for global capitalism. Much of the history of the continent during this period was characterized by poverty, precarious labor relations, and the absence of state or company welfare measures, as well as the failure or the lack of efforts to challenge precariousness. This paper analyses the social question in Africa since the colonial period with a focus on social (in)security and labor against the backdrop of a related research literature that largely ignores the continent. In the rich field of social sciences' studies of the welfare state, Africa does not feature prominently, to say the very least. Esping-Andersen's famous typology of welfare states completely ignores Africa. ${ }^{2}$ In the index of the more recent, authoritative Oxford Handbook of the Welfare State, Africa is only listed twice, and these references are related to trade unions and unemployment insurance. When we look at the referenced pages, we learn only that unionization rates are lowest worldwide throughout much of Africa and that Africa is the weakest area of social insurance development. ${ }^{3}$ For a long time, Africa seems to have served as the epitome of "otherness," not only in the history of welfare and labor but also in much Western scholarship. A Europe- or West-centered perspective still often places Africa at the other end of the developmental spectrum-a clear instance of a region that simply does not fit the patterns familiar to a North Atlantic framework. However, as will be argued here, the history of the social question in Africa has a great many lessons to offer to those who are interested in tracing the historical connections between 
regions and in critically engaging with the idea of the North Atlantic world as "normal" and the rest as "exceptional" and "in need of explanation." If our historical analysis of the social question has to transcend the notion of a single telos modeled after the example of the West that is supposed to be achieved everywhere, or if we are to go beyond the conception that the non-realization of this telos represents somehow a "lack" or a "lag" in those societies to understanding their specific examples coevally — to echo Johannes Fabian's insight ${ }^{4}$ - with that of the West, then we must take the different social forms in Africa seriously in all their complexity and all their linkages with welfare and labor forms elsewhere.

This paper chronologically discusses the social question with a focus on subSaharan Africa and emphasizes a context in which capitalist production regimes have not led to employment relations typically characterized by stable and protected wage labor. ${ }^{5}$ While often drawing from examples from specific regions, it attempts to provide a broad historical view on larger trends and transformations of the social question in Africa, referring to a literature that tackles questions of welfare, social security, and social marginality within a wide array of topics such as labor, state, or urbanization.

\section{WHITES ONLY: COLONIALISM AND WELFARE BEFORE WORLD WAR II}

Until World War II, the colonial state and European private employers delegated the field of social security and poverty care more or less completely to what they labeled "traditional African solidarity," occasionally also to a few private and especially church welfare institutions. There is little detailed information about related initiatives. ${ }^{6}$ In 1931, for instance, the Holy Ghost Fathers alone managed 132 orphanages and 176 hospitals or dispensaries in sub-Saharan Africa. During the following year, 648 people passed through the poor asylum run by the Sisters of Cluny at Walezo in Zanzibar. Missionaries also provided most of the rapidly expanding institutional care of leprosy. In some parts of Africa, mostly in the settler colonies, the Salvation Army undertook some welfare work among Africans. The Red Cross, the world's first international secular charity and the first to establish itself in Africa, mainly worked among European communities in French and Belgian Congo. In British colonies, local governments made little provision for the poor beyond some general services such as famine control, free (but very limited) public health services, or rudimentary urban sanitation.?

In his influential African Survey, published in 1938, Lord Hailey, the great theoretician of British colonial rule, praised the practice of "externalizing" systems of social security. He stated that "it is clear that by treating the native reserves as reservoirs of man-power, there is, in effect, a saving in that outlay on social services which in other circumstances might have to be incurred on behalf of industrial-

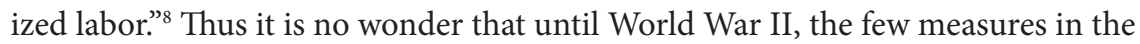


realm of social policy benefited Europeans almost exclusively. Programs associated with the "modern" welfare state were first and most comprehensively introduced in South Africa, where noncontributory, means-tested old-age pensions were created for elderly people classified as "white" or "colored." For the National Party and Labor Party-partners in the coalition Pact Government of 1924-1929noncontributory old-age pensions were a crucial pillar in the "civilized labor" policies designed to lift "poor whites" out of poverty and reestablish a clear racial hierarchy. Welfare reform was thus, in significant part, a response to the swart gevaar, or menace of black physical, occupational, and social mobility. ${ }^{9}$ Programmatic provision was extended to the disabled, poor mothers with children, and the unemployed. By the late 1930s, South Africa had a comparatively well-developed welfare state for its white and colored citizens. Similar noncontributory old-age pensions were introduced for white residents in Southwest Africa and Southern Rhodesia. The construction of welfare states in these settler societies reflected a combination of elite ideology, shaped both by racist and progressive elements, and democratic politics within the enfranchised white and colored population.

In other parts of Africa, it was only in the field of health where, after 1900, some colonies like German East Africa (which became Tanganyika after World War I) introduced decrees concerning industrial law that were relevant to a small minority of African workers. ${ }^{10}$ In 1909 the governor of German East Africa issued a "decree concerning the rights of indigenous workers" that introduced the duty of employers to guarantee medical care of their employees. However, this measure was seldom put into practice. In 1923 the British passed the Master and Servants Ordinance, which provided for small compensation to be paid by employers in the case of industrial accidents. African government clerks were initially classified into lower administrative ranks with neither pension rights nor other employers' contribution. The Provident Fund (Government Employees) Ordinance, issued in November 1942, introduced a fund also for lower ranks that provided for at least small payments in the case of retirement or premature inability to work. ${ }^{11}$

Right from the beginning of colonial rule, access to labor was crucial to European colonizers in Africa. However, before World War II, this importance was reflected neither in the administrative order nor in colonial archives. Until the mid-1930s there was hardly any African colony with a "labor department." In its prewar heyday, colonialism, even when administered by relatively democratic governments in the home context, evaluated its African subjects essentially as primitive and ineffably "different" tribesmen with a patriarchal and rural mold. The conservation of an ossified tribal Africa coupled with the extraction of unskilled seasonal or casual labor was common wisdom. The debates of the day were about the necessity for forced labor and the extent to which Africa was becoming diseased and depopulated due to colonial labor demand. Dynamism in this system was confined to white settlers or energetic Levantine and Asian traders. ${ }^{12}$ Against this backdrop, colonial officials found it convenient to leave agricultural 
production to former slave owners and chiefs, or enlist their aid to supply the labor required for public, and even private, purposes. Moreover, desperate to make their territories economically viable, they resorted to various devices for mobilizing unfree labor themselves, including forced labor, conscription into the army or police forces, and the recruitment of contract labor by all kind of dubious means. The Portuguese colonies were particularly notorious for relying on forced labor, and parts of Portuguese-ruled Africa fell at the far end of a spectrum of brutality of labor practices. However, at least until the 1940s, institutionalized violence to extract African labor was by no means solely a Portuguese approach. ${ }^{13}$

After World War I, the newly founded League of Nations took up this issue. The debates culminated in the Forced Labor Convention of the International Labor Organization of 1930. ${ }^{14}$ The realities on the ground in Africa were much more complex, and the hierarchies and forms of exploitation much more subtle than what the discussions about forced labor in Geneva addressed. Moreover, neither the missionary critics who asked "Africa: Slave or Free?" nor League of Nations investigators questioned the premise of colonial rule itself; consequently, the resulting debate sought only to draw distinctions among labor policies considered acceptable and not acceptable in a European-dominated Africa. Officials in the colonies wanted to use the labor of Africans as much as they could, but at the same time, they firmly believed in the necessity of stable African communities under the control of male elders. European administrators saw mining towns or cities as sites of labor, but not of the reproduction of the labor force. Those Africans who had left this imagined traditional village life and permanently settled in the cities were labeled "detribalized." 15

During the Great Depression, the first substantial debates about the problem of unemployment emerged. According to John Iliffe, "the great novelty of the depression was tropical Africa's first serious experience of unemployment." ${ }^{16}$ In the formal sector, in branches where Africans worked under contracts, a rapid decline of working places took place during the early 1930s. Between 1930 and 1933, the copper mines in Katanga reduced their African workforce from 73,000 to $27,000 .{ }^{17}$ However, only a small portion of the African population was officially "working" and thus qualified for appearing in statistics. In French West Africa, 120,000 people were in official employment in 1933, plus 39,000 migrant peanuts laborers in Senegal, 1.1 percent of the population. ${ }^{18}$ The Inspecteur du Travail of French West Africa remarked in 1934 on the absence of unemployment but had a circular definition of it: since the African family took care of its members and had access to land, only the most detribalized Africans, notably urban artisans, could be unemployed. Such an argument is "indeed a telling instance . . . of how belief in the peculiar nature of African society could define an entire problem out of existence." ${ }^{19}$ One example of this circular argument comes from a report of 1936: "There are no unemployed in French West Africa. Anyone who so desired could go back to the soil and any worker who does not prefers to vegetate in the 
city which he only will leave at the last extremity. There is thus constituted a floating urban population of 'sans-travail' of a particular nature, seeking daily labor without enthusiasm, living most often at the expense of more favored brethren." A year later the Inspecteur du Travail indicated that he did not believe that African workers were quite like other workers. He opposed unemployment compensation, saying, "I am not a partisan of unemployment indemnities in a country where the soil can nourish those who wish to cultivate it."20

\section{DECOLONIZATION AND THE SHORT SUMMER OF THE WELFARE STATE}

These assumptions began to be challenged in the 1930s, first by minority voices and then, as one approaches the 1950s, on a broader front. For this, there were various reasons, not least the realization that such policies led to semi-stagnation in a world where development became more and more an imperative. ${ }^{21}$ The suddenly manifest capacity of African workers to organize and throw a wrench in the works of the extractive economy was, however, also of fundamental importance. ${ }^{22}$ Arguments mounted that African workers needed to be treated as workers, not as Africans. They should be permitted to form trade unions, critically, a strategy of containment and boundedness. And they should benefit from a social welfare system. The colonial state tried to conceptualize structures that would allow for a stable detribalized urban working class in towns, focused on a European family model. "By the mid to late 1940s," Fred Cooper writes, "influential officials wanted Africa to have a working class, to separate an identifiable group of people from the backwardness of rural Africa, attach its members to particular jobs and career ladders and over time make them into a predictable and productive collectivity." ${ }^{23}$

Over the following decade, colonial administrators and experts worked on a new labor policy that was called "stabilization." This term referred to the fact that in the eyes of the Europeans involved, the task in Africa was not to make wage labor the basic form of production, as in ideal-type capitalism, but to separate a domain of wage labor from a domain of traditional production. Above all, colonial administrations had to be insured that the reproduction of the wage-earning class would take place uncontaminated by the "backwardness" that apparently lay outside it, in the villages. In many reports, a vision of a male African appeared who was weaned from dependence or nonwage income and lived with his wife and family in an urban location, sending his children to school and, over time, becoming acculturated to industrial and urban life. The gender bias in all of this was too self-evident for much contemporary discussion. Throughout the colonial period, employment and unemployment were overwhelmingly associated with men. For long, women had entered urban centers and, with waged employment deemed appropriate for them being restricted, had made a significant contribution to sectors outside the realm of wage work. However, no one at the time commented on the fact that the 
definition of the worker in the Code du Travail for French West Africa-the result of intense debates between French officials and African trade unions and accompanied by numerous strikes - placed the kind of tasks that women most often did outside the law's conception of work. That women were crucial to the commerce of West African cities or that they performed a great variety of income-generating activities did not enter into the discussion of any aspect of the code. ${ }^{24}$

The rising global importance given to social security after World War II is reflected by the UN Declaration of Human Rights of 1948, which stated that "everyone, as a member of society, has the right to social security." Already four years earlier, a declaration had emerged from the ILO conference in Philadelphia that announced that "labor is not a commodity" and called for international effort for the "common welfare." Furthermore, it sought measures "to provide a basic income to all," for regulation of working hours, for collective bargaining, and for measures to improve public health, housing, nutrition, education, child welfare, the status of women, and public services. The last paragraph of the document emphasized that the principles listed were "fully applicable to all people everywhere"; it called specifically for "their progressive application to peoples who are still dependent, as well as to those who have already achieved self-government." ${ }^{25}$ Soon after, the ILO began to develop its "social policy in dependent territories," which set out to globalize its "standards" on work regulations, housing, education, health, and family life. ILO resolutions were weak on supranational enforcement mechanisms and did not mandate the colonial powers in Africa to act in a particular way, but legitimized and delegitimized certain policy strategies. In some ways, Britain and France thought that the "social" direction put forward by the ILO was consistent with their reformed postwar colonialism and even celebrated the 1952 ILO convention "Minimum Standards of Social Security" as the "internationalization" of their respective social policies. However, the standards soon hit a wall. The British held the view that their African colonies should raise the revenues necessary to pay for social security themselves. Given the financial situation of their territories, the implementation of substantial social security systems was delegated to a distant future. ${ }^{26}$

In 1958 the ILO published the African Labour Survey, which made some reflections about the state of social security as part of the stabilization project on the continent. The authors saw "evidence of the interest of the authorities in Africa in the possibility of introducing social security measures and their awareness of the urgency and growing importance of the question." However, they also listed the factors that, according to them, militated against the successful introduction of social security, for instance "the instability of the labour force, the low level of wages, the inadequacy of population registers, polygamy, the illiteracy of workers and even of small employers in rural areas, poor communications and the difficulty of supervising migrant workers who, at times, disappear, never to be heard of again." Still, they happily acknowledged that "it is generally accepted that one way 
of stabilising labour is to give workers effective protection against occupational and other risks." ${ }^{27}$

Admittedly, this new approach was often expressed in a restrained manner, as in 1952 in the Tanganyika Standard: “The average African labourer has sprung from generations of men content to sit under the shade of the nearest tree and do little or no work whatsoever. . . But, the African, while inherently lazy, is by no means beyond redemption. . . . If he can adapt himself to regular employment under conditions where food, accommodation, medical and other amenities are available, he can and does become worthy of his hire." ${ }^{28}$ Still, in contrast to prevailing low-wage, labor-extensive forms of employment, from the 1950s, increased skill levels were rewarded with higher salaries. Paradoxically, this increase in wages formed a prime cause of growing urban poverty. According to John Iliffe, it "attracted people into towns, encouraged employers to replace workers by machinery, and bred the unemployment, overcrowding, and ancillary problems which the authorities had intended to prevent." ${ }^{29}$ A background context profoundly shaping the phenomenon was demographic change. Rapid African population growth from the mid-twentieth century, alongside a diminishing resource-to-population ratio, resulted in a shift from famine-related "epidemic starvation for all but the rich . . . to endemic undernutrition for the very poor." ${ }^{\circ}$ One of the most prominent forms in which this "structural" poverty manifested itself was the growth of urban joblessness. In the context of rapid urbanization, the problem of a reserve army of unemployed or jobless young men observable in towns caused increasing attention.

In a number of African colonies, a set of social institutions was created for relatively small groups of formal-sector workers. One striking aspect about social welfare measures in late colonial Africa is, however, that unemployment insurances were never seriously discussed. In the 1950s, unemployment in urban Africa was recognized and discussed by contemporaries, but belittled by colonial officials. ${ }^{31}$ The Code du Travail for French Africa from 1952 contained no fewer than 241 articles and provided for a comprehensive arsenal of welfare measures. However, there was no mention at all of unemployment compensation. ${ }^{32}$ The ILO in its African Labour Survey observed "considerable underemployment" on the continent, but concluded that "unemployment, except in a few towns in the form known in highly industrialized countries, exists only to a limited extent; there are usually more offers of employment than applications for jobs." 33 In most late-colonial labor laws, unemployment compensation was held to be particularly undesirable, because most officials would not acknowledge that the African wage earner who was not working was, in fact, a worker. One also has to emphasize the gendered way in which the "unemployment problem" was interpreted. In the official imagination, it was once more male youth who constituted a potentially insurrectionary unemployed class, who were more visible "loitering" on urban streets. The absence 
of female unemployed in surviving commentary reflects the gendered occupation of urban space. In contrast to young men, whose street presence has remained a concern up to the present, women were more restricted to the home and/or the workplace. Or they simply did not constitute a threat in the eyes of the male colonizer. ${ }^{34}$

Especially in the French African colonies, the main instruments in social welfare policies were family allowances. After long and controversial debates, and due to massive pressure from African trade unions, on January 1956, family allocations went into effect in French West Africa, six months later in French Equatorial Africa. In Senegal, a family would receive 4,800 francs "allocation du foyer" for the birth of each of its first three children; each pregnancy would bring the family 3,600 francs prenatal allocation and 4,800 francs maternity allocation; in addition, 400 francs per month would be paid as the basic family allowance for each dependent child, through the end of his or her schooling. The 400 francs per month would be around 8 percent of the minimum wage; the maternity allocation, around a month's minimum pay. Such allocations would make a considerable difference to the life of a worker. The decrees provided support for the children of female workers as well as of male; there was even a special provision for benefits for wage-earning women who gave birth. But the expectations of the planners were that of the male worker and the female child-care provider. In the studies on which these cost estimates were based, the surveyed population in industry included 25,357 African males, but no females; in commerce, there were 14,045 males and 105 females. The language in which officials addressed the burdens of raising children on a worker's salary was comfortably masculinist, and officials allocated, using their workforce data, minimal funds for working mothers.

The implementation of family allowances got off to a slow start. One reason was that the administration had the utmost difficulties to put these schemes into practice, because the required information, such as documentations of birth, was difficult to obtain. Still, by 1956 , family allocations had been extended to the entire wage-labor force of French West Africa, and officials now embraced them for much the same reason that they rejected them earlier-the peculiar nature of the African family. But now it was a question of weaning workers away from its debilitating effects, of creating family norms that resembled those presumed to predominate in Europe, of insuring the reproduction of a working class on the basis of workers' earnings and within the milieu of the workplace..$^{35}$

In many ways, the dualism imagined by the colonial administrators and experts of a small, restricted modern African working class separated from the "traditional rest" was a mere fantasy. African workers in regulated jobs did not cease to be African; they did not cut themselves off from the wider range of social and cultural relationships in their lives, including their home villages. They regularly opted to live in a family arrangement rather than that of the monogamous male 
breadwinner with his dependent wife and children. They began to invest in the education of their children and to accumulate savings and pension rights toward retirement. However, they did not necessarily simply accept the notions of the European welfare state, but often used part of their wage resources to invest in social networks and rituals to foster their patriarchal authority. ${ }^{36}$ African tradeunion leaders were rather successful in using European officials' hopes for a productive, "modern" working class in order to make claims. They argued that if the Europeans wanted Africans to produce like a European working class, then Africans should be paid like their counterparts in Europe. Wages increased considerably, especially in key industries, in the civil service, and for vulnerable areas like railroads and ports. These increases were by no means uncontested but rather the result of protests, strikes, and negotiations. ${ }^{37}$

In effect, the colonial state could not respond to demands for increased benefits and rights from organized labor-which would put its members on par with metropolitan workers-without dismantling the justification of colonialism. There is an ironic charm-but also a kind of Pyrrhic victory-in the African success in defeating European developmentalist logic. One could view the decision by Europeans to accept unionist demands that African laborers be treated on the same basis as their European counterparts as a mutual failure to comprehend the African social reality. It was a consequential failure, since the cost of providing European-scale wages and benefits under African economic conditions could not be borne by either colonial or postcolonial regimes. European governments were thus encouraged to withdraw from Africa, while their local successors coopted some of the labor leadership but rather quickly suppressed the unions as an autonomous force. The leaders of the newly independent countries, former tradeunionists among them, were acutely aware that they lacked the resources to ensure that the demands of the citizenry would be met. Many of them build up relations of patronage with power brokers inside the nation but also clientelistic networks with former colonizers. By this, they undermined democratic processes and the kind of social movements, such as labor movements, that had helped them get into power. ${ }^{38}$

\section{HOPES AND DISILLUSION: INDEPENDENT AFRICA AND THE RISE OF THE INFORMAL}

Around 1960, when many African colonies gained independence, numerous observers thought that with population growth having accelerated after 1945, and with the urban population growing faster than the rural, a class of landless manual workers would be created, and Africa would reproduce European patterns. But wage laborers made only a small percentage of the overall working population in Africa, both in colonial and postcolonial times. It was, however, exactly this small group of miners, dockworkers, factory workers, and railway workers that 
constituted the focus of African labor historiography between the 1960s and 1980s. The academic focus on wage labor went hand in hand with the assumption that Africa was becoming "proletarianized"; its working class was growing and becoming better defined and more self-conscious. ${ }^{39}$ From the late 1950 s to the 1970 , many African countries experienced at least modest economic growth, life expectancy rose considerably, and education became more accessible. The emergence of elements of a welfare state raised considerable expectations. State employees, workers in copper mines, or railway workers, for instance, had reasonable hopes that they could get something out of participation in economic activities. But these decades proved to be not a mid-point in a natural "transition" from a nonwage-labor to a wage-labor economy in a welfare state. While it is difficult to count precisely, it is clear that the number of hired workers in sub-Saharan Africa was vastly greater by 1960 than it had been in 1900, and is much greater today than it was around the time of independence. Yet labor markets since the end of colonial rule are characterized much more by short-term hiring and a high turnover of workers than by long-term, stable employment. Precarious labor prevailed, both in the formal and in the informal sector. ${ }^{40}$

The seemingly reasonable aspirations of millions of Africans of turning jobsespecially stable, unionized jobs, with pension funds promised at the end-into careers proved unrealizable. The mining sector in the Zambian copper belt initially promised steady material rewards-a salary and health and retirement benefits-as well as other, more ineffable rewards in terms of cultural cachet and social status. That pathway to working-class stability and respectability soon came to an end with the oil crisis, structural adjustment programs, and the fluctuating global prices of copper. What meager resources these miners kept for their old age came not so much from the formal institutions of modern welfare capitalism-social security, pensions, medical insurance-or the contractual gains won by trade unions, but from sets of personal relationships that ex-miners could draw on or forge. ${ }^{41}$ Petty trade, access to farmland through social relations in a village of origin, or support of kin-networks became necessary to survive in the context of a contracting regulated wage-labor sector. The notion of being a "big man," an element of men's self-esteem that had been given a new dimension by wage earning, increasingly had to confront the fact that women engaged in urban marketing and other activities were contributing more to the family economy and providing the stability that male wages could not. The bureaucratized world of work had not been eclipsing the world of social relations; if it had done so, the collapse would have been even more deadly than it was.

Today, young men whose social power long rested on their ability to earn wages increasingly find themselves in a more precarious position. In turn, others, notably women and pensioners, acquired new powers and possibilities. This transformation is partly due to the relative expansion of work in service industries that are more open to women than the blue-collar industrial jobs of the past. ${ }^{42}$ The 
increasing instability of economic prospects in many African countries today has also changed migration patterns. Seasonal labor migration, which was central to African economies in the first half of the twentieth century, has been overtaken by more permanent rural-urban migration and by large-scale labor migration to Europe and beyond. Africans are more likely to travel longer distances in search of employment. In the twenty-first century, many African countries have apparently become increasingly dependent upon the productive activities and remittances of their citizens who live abroad in other African countries or in Europe, Asia, the Gulf States, or the United States. ${ }^{43}$

By the 1970s, the ILO began to use the evocative but sloppy term "urban informal sector" for the urban dimension of what did not fit inside national labor legislations and a bounded, stabilized working class. The term points to the continued-indeed, growing-importance of forms of work that lie outside the form of labor legislation that African countries inherited at independence and outside the limits of the imagination of policy makers who thought they were modernizing Africa. ${ }^{44}$ Although some Africanists insist that "African economies are the most informalized in the world," nonwaged economic activities, unregulated by law and unprotected by social regulations or services, have become increasingly visible in many parts of the world, including the North Atlantic region. ${ }^{45}$ The discovery of the "informal" went in hand in hand with the observation that full-time wage labor with relatively good social benefits over the course of an entire career was not a global norm, but rather the exception in many parts of the world, the contingent product of a particular conjuncture in twentieth-century world history.

A critical literature seems to agree on the inadequacy of the term "informal" but has failed to produce alternative terminology. ${ }^{46}$ I would argue for an understanding of "informal labor" not as a residue of earlier and obsolete modes of socially organizing labor. Rather, it should be understood as a contemporary and adaptable sociopolitical category that distinguishes a heterogeneous and unstable set of transformed and new "informal," mainly socially regulated labor forms from an equally diverse and malleable set of "formal," predominantly state-regulated labor forms. These two sets of labor forms are mutually constitutive and interdependent, and they have assumed diverse features and proportions over the course of historical time, as well as in different local and territorial contexts. The social content and the interrelationship of "informal" and "formal" labor is shaped and persistently transformed by economic and social policies, business strategies, and social conflicts. Accordingly, the politics of informal labor is often connected to efforts at the resolution of crises of capitalist over-accumulation, including efforts to solve such crises by way of spatial expansion and relocation. It is crucial to emphasize the political character of formal/informal divisions in the contemporary world of labor across the continents, as well as to reconstruct the historical genesis of this divide. It is not by accident that as an academic and political concept, "informal 
labor" gained currency in the course of the 1970s, the middle of that decade being a crucial chronological marker for a major shift in the pattern of economic and social policies, business strategies, and social conflicts the world over. In fact, the career of the term "informal sector" may be linked to the rise of the political and ideological formation that is commonly referred to as "neoliberalism." Thus, it would be important to study more carefully the political and social processes that had rendered the informal/formal division conceivable. Finally, many activities labeled "informal" are not relatively new and exclusively spawned by neoliberal reforms and structural adjustment programs of the 1980s. Such assertions would overlook the deep roots of African productive systems and the relationships that contemporary skilled workers and craftsmen share with older services and forms of fabrication. Indeed, one of the shortcomings of studies on informality is that they often present snapshots of specific activities and processes, but they do not necessarily locate them within larger trajectories of historical change. ${ }^{47}$

While the term "informal" might be problematic and not sufficiently differentiated as an analytical tool, it refers to processes crucial to the social question in Africa. When the world economic recession of the 1970s hit Africa hard, most governments were forced to seek aid from the International Monetary Fund and other international institutions, which, in turn, enforced the destruction of much that could be considered "social." The right to education, medical care, and a livable wage were undermined in the name of financial rigor. Cutbacks in the public sector and in social programs eroded the number of waged employees. Households were forced to diversify their sources of income, and people involved in informal activities increasingly suffered from their work's uncertain juridical status and the volatility of their finances. Small-scale workshops were often characterized by low surplus and strong competition and were usually not more than severely undercapitalized and unskilled businesses. Market women particularly suffered, as they faced the falling incomes of poor and working-class customers, and more and more they had to compete with men who began working as street vendors after losing their waged jobs. ${ }^{48}$ What also could be observed was "dividing a given activity in ever-finer morsels." ${ }^{49}$ As Fred Cooper emphasized, "a young man, who in the 1970s would have sold tiny packets of peanuts in the streets of Dakar or in the 2000s low-denomination phone top-up cards, finds a niche because his labor is worth so little that an entrepreneur can employ him to sell things to people too poor to spend a significant sum of money at a time."50 This reality on the ground stood in stark contrast to celebratory statements of the World Bank or NGOs highlighting the energy and skill of the small-scale entrepreneur. There is the bitter irony that empowerment through informal enterprise so cherished by neoliberal commentators was undermined by neoliberal politics that drastically weakened the very institutions-such as family, education, and basic safety nets-upon which informal entrepreneurship is based. ${ }^{51}$ 


\section{CONCLUSION: PRECARIOUS AFRICA?}

The terrifying leviathan "assumes more and more the traits of a milk cow," the conservative German philosopher Arnold Gehlen stated some forty years ago in his polemic against mass democracy and the welfare state. In the meantime, we see that politicians in the industrialized countries prescribe various diets and fitness training for this milk cow. The situation is very different in Africa, however. Because of the low importance of formal, institutionalized labor markets, statesponsored systems of social security were never widely spread south of the Sahara anyway. During the twentieth century, these state systems had only very limited and socially selective spheres of operation, which, after a peak in the 1960 and early 1970s, constantly diminished over the last decades. On the other hand, those institutions, practices, and resources of "welfare production" that were not under state management enjoyed great importance. In this context, government officials, development experts, and scholars alike usually referred to the "traditional solidarity" of African families and communities. Already in the colonial period, European administrators returned to this "solidarity," because it was supposed to arrange what to colonial officials-despite all rhetoric-seemed far too expensive: absorbing, at least partially, the manifold risks of working life.

African independent states inherited a complex and potentially explosive combination of authoritarian governance, high expectations for improved living conditions, a limited extent of formal employment, and already fragmented trade unions. Thus, even before the devastating impact of the oil crisis, followed by structural adjustment programs, wage labor was never available as the foundation of an egalitarian and democratic society. Labor coercion and personal dependence did not disappear; it was often facilitated by poverty at all levels. The colonial discourse of development that began in the 1930s and continued after independence relabeled work that otherwise could have been classified as forced labor as "voluntary work," "self-help," or "human investment." In this process, certain sections of African labor were rendered invisible as workers and instead constructed as "beneficiaries," "participants," and "volunteers." ${ }^{52}$ The issue of forced labor continued to be debated after independence. In 1962, the ILO Committee of Experts on the Application of Conventions and Recommendations criticized a number of recently independent African countries, such as Guinea and the Ivory Coast, for having set up new forms of forced labor in the form of compulsory labor services for young people. As Daniel Maul points out, "To be accused of a 'classically colonial crime' such as forced labour was particularly hard for the postcolonial nations to stomach," and they reacted bitterly.53 The problem of "un-freedom" never went away: it is diffused and can be found in many sectors or embedded in various labor relations. In 2016, the ILO estimated that "there were a total of over 9.2 million victims of modern slavery in Africa." ${ }^{54}$ Immigrant workers from Africa are part of this number. The question is how to label all those Africans who, by 
their own initiative, cross the Mediterranean Sea to Italy or Spain, or the Atlantic to the Canary Islands, to seek wage labor? Those Africans who, between the sixteenth and nineteenth centuries, were sent across the Atlantic to work on slave plantations in the Americas were coerced, and they were called "slaves." Today's migrants, however, are in some ways the freest of the free: "they not only agree to leave Africa for Europe, but they go to great effort and great risk to do so." ${ }^{55}$ Often people with some means and education dare the dangerous and expensive trip, with the idea to make some money in Europe in order to support the family back home. Those Africans who make it to Europe, usually after a traumatic voyage via the desert and the Mediterranean, definitely work under conditions that deserve the label "precarious." Their ideas about a Europe full of opportunities soon vanish. They are mostly sans papiers and thus subject to deportation or exploitation by employers who misuse their vulnerability. ${ }^{56}$

It would be misleading to see informal and precarious work only as a new phase in capitalism in which workers in many parts of the world, and most notably in Africa, have become unnecessary, disposable. Multinational capital might still need many workers from Africa, as long as they are cheap, particularly to reach customers of modest means. ${ }^{57}$ Moreover, precarity could be seen as a constitutive feature of capitalist labor, inasmuch as uncertainty and instability have always been inherent characteristics of wage labor, in Africa as elsewhere. ${ }^{58}$ Yet political mobilization of and collective bargaining for precarious and informal workers remain a challenge. In West Africa, for example, the share of informal employment ranges from 76 percent (in Senegal) to 93 percent (in Benin) of the labor force; the total unionization rate was 12.8 percent in $2007 .{ }^{59}$ However, given the ongoing increase of "land grabs," with states helping to alienate land to both foreign and domestic capitalists, in combination with the increasing pressure of the population on land and on soil fertility, it is not unlikely that landlessness will supersede the lack of labor power as the major source of poverty in Africa.

\section{NOTES}

1. Jan Breman and Marcel Van der Linden, "Informalizing the Economy: The Return of the Social Question at a Global Level," Development and Change 45, no. 5 (2014): 920.

2. Gosta Esping-Andersen, The Three Worlds of Welfare Capitalism (Princeton, NJ: Princeton University Press, 1990).

3. Francis G. Castles, Stephan Leibfried, Jane Lewis, Herbert Obinger, and Christopher Pierson, eds., The Oxford Handbook of the Welfare State (Oxford: Oxford University Press, 2010), 209, 434. For some recent attempts of social scientists to look at the social question in Africa from a historical perspective, see Alex Veit, Klaus Schlichte, and Roy Karadag, "The Social Question and State Formation in British Africa: Egypt, South Africa, and Uganda in Comparison," European Journal of Sociology 58, no. 2 (2017): 237-64; Carina Schmitt, "Social Security Development and the Colonial Legacy," World Development 70 (2015): 332-42. For a recent state of the art volume on African labor history that includes numerous references to the social question, see Stefano Bellucci and Andreas 
Eckert, eds., General Labour History of Africa: Workers, Employers, and Governments 2oth-21st Centuries (Woodbridge, England: James Currey, 2019).

4. Johannes Fabian, Time and the Other: How Anthropology Makes Its Objects (New York: Columbia University Press, 1983).

5. For a useful conceptual history of the term social question, see Holly Case, "The 'Social Question, 1820-1920," Modern Intellectual History 13, no. 3 (2016): 747-75. The crucial role of the working class in twentieth-century struggles around the social question is emphasized by Breman and Van der Linden, "Informalizing the Economy."

6. For the following examples, see John Iliffe, The African Poor: A History (Cambridge: Cambridge University Press, 1987), 195-200.

7. See Ulrike Lindner, "The Transfer of European Social Policy Concepts to Tropical Africa, 19001950: The Example of Maternal and Child Welfare," Journal of Global History 9, no. 2 (2014): 208-31. For a broad view on the British Empire, James Midgley and David Piachaud, eds., Colonialism and Welfare: Social Policy and the British Imperial Legacy (Cheltenham: Edward Elgar, 2011).

8. Lord Hailey, An African Survey: A Study of Problems Arising in Africa South of the Sahara (Oxford: Oxford University Press, 1938), 710.

9. Jeremy Seekings, "'Not a Single While Person Should Be Allowed to Go Under.' Swartgevaar and the Origins of South Africa's Welfare State, 1924-29," Journal of African History 48, no. 3 (2007): 375-94. See also the chapter by Ben Scully in this volume. The exclusion of black Africans from welfare measures went hand in hand with conceptions of native work ethics that did cast blackness as an antagonistic other, usually associated with images of indolence and work avoidance. See Franco Barchiesi, "The Violence of Work: Revisiting South Africa's 'Labour Question' through Precarity and Anti-Blackness," Journal of Southern African Studies 42, no. 5 (2016): 875-91.

10. Andreas Eckert, "Regulating the Social: Social Security, Social Welfare and the State in Late Colonial Tanzania," Journal of African History 45, no. 3 (2004): 473-74.

11. John Iliffe, A Modern History of Tanganyika (Cambridge: Cambridge University Press, 1979),

12. Frederick Cooper, Decolonization and African Society: The Labor Question in French and British Africa (New York: Cambridge University Press, 1996), chap. 2.

13. Eric Allina, Slavery By Any Other Name: African Life under Company Rule in Colonial Mozambique (Charlottesville: University Press of Virginia, 2012); Alexander Keese, "Searching for the Reluctant Hands: Obsession, Ambivalence, and the Practice of Organizing Involuntary Labour in Colonial Cuanza-Sul and Malange Districts, Angola, 1926-1945," Journal of Imperial and Commonwealth History 41, no. 2 (2013): 238-58. For a nuanced study of the connections between migrant labor and forced labor in a later period, see Zachary Kagan Guthrie, Labor, Mobility, and Colonial Rule in Central Mozambique, 1940-1965 (Charlottesville: University of Virginia Press, 2018).

14. See J. P. Daughton, "ILO Expertise and Colonial Violence in the Interwar Years," in Globalizing Social Rights: The International Labour Organization and Beyond, ed. Sandrine Kott and Joelle Droux, 85-97 (Houndsmills, U.K.: Palgrave Macmillan, 2013); Frederick Cooper, "Conditions Analogous to Slavery: Imperialism and Free Labor Ideology in Africa," in Beyond Slavery: Explorations of Race, Labor, and Citizenship in Postemancipation Societies, by Frederick Cooper, Thomas C. Holt, and Rebecca Scott (Chapel Hill: University of North Carolina Press, 2000), esp. 132-34. One important text voicing contemporary concerns about abuses in labor recruitment was Raymond Leslie Buell, The Native Problem in Africa, 2 vols. (New York: MacMillan, 1928). For the broader context of the rise of international organizations and most notably the role of the League of Nations during the interwar years, see Patricia Clavin, Securing the World Economy: The Reinvention of the League of Nations, 1920-1946 (Oxford: Oxford University Press, 2013); Susan Pedersen, The Guardians: The League of Nations and the Crisis of Empire (Oxford: Oxford University Press, 2015).

15. Cooper, "Conditions Analogous to Slavery," 129. Note that in this context also women participated in migratory initiatives in order to get away from patriarchal authority. See Marie Rodet, 
"Forced Labor, Resistance, and Masculinities in Kayes, French Sudan, 1919-1946," International Labor and Working Class History 86 (2014): 107-23.

16. Iliffe, The African Poor, 155 . Some authors refer to the fact that in some parts of Africa, unemployed labor was already an issue at the beginning of the century. For instance, in 1905 unregulated settlements of about twenty thousand unemployed were reported in Entebbe. See Thomas Fuller, "African Labor and Training in the Uganda Colonial Economy," International Journal of African Historical Studies 10, no. 1 (1977): 84 .

17. Bogumil Jewsiewicki, "The Great Depression and the Making of the Colonial Economic System in the Belgian Congo," African Economic History 4 (1977): 158. More broadly on the effects of the depression on Katanga miners, see John Higginson, A Working Class in the Making: Belgian Colonial Labor Policy, Private Enterprise, and the African Mineworker, 1907-1951 (Madison: University of Wisconsin Press, 1989), chaps. 4-6; Julia Seibert, In die globale Wirtschaft gezwungen: Arbeit und kolonialer Kapitalismus in Kongo (1885-1960) (Frankfurt: Campus, 2016), part 3.

18. Cooper, Decolonization, 43. More generally on the wage labor sector in Senegal before World War II, see Babacar Fall, Le Travail au Sénégal au XXe Siècle (Paris: Karthala, 2011), 71-132.

19. Cooper, Decolonization, 42.

20. Quotes in ibid., 485, n. 67.

21. The history of the development concept and related practices have been intensely studied over the last two decades. See, among the numerous publications, Frederick Cooper and Randall Packard, eds., Development and the Social Sciences: Essays on the History and Politics of Knowledge (Berkeley: University of California Press, 1997); Joseph Hodge et al., eds. Developing Africa: Concepts and Practices in Twentieth-Century Colonialism (Manchester: Manchester University Press, 2014); Hubertus Büschel and Daniel Speich, eds. Entwicklungswelten: Globalgeschichte der Entwicklungszusammenarbeit (Frankfurt am Main: Campus, 2009).

22. The history of strikes and labor movements constituted an important part of African labor historiography, but it was rarely conceptualized within the paradigm of social movements. See Andreas Eckert, "Social Movements in Africa," in The History of Social Movements in Global Perspective. A Survey, ed. Stefan Berger and Holger Nehring, 211-24 (London: Palgrave Macmillan, 2017).

23. Cooper, Decolonization, 14.

24. Frederick Cooper, "African Labor History," in Global Labour History: The State of the Art, ed. Jan Lucassen, 91-116 (Berne: Peter Lang, 2006); Cooper, Decolonization.

25. The International Labour Organization Declaration Concerning Aims and Purposes (May 10, 1944), http://avalon.law.yale.edu/2oth_century/decade15.asp. On the Philadelphia declaration, see Alain Supiot, The Spirit of Philadelphia: Social Justice versus the Total Market (New York: Verso, 2012); Frederick Cooper, "Social Rights and Human Rights in the Time of Decolonization," Humanity 3, no. 3 (2012): 473-92.

26. Daniel Maul, "The International Labour Organization and the Globalization of Human Rights," Human Rights in the Twentieth Century, ed. Stefan-Ludwig Hoffmann (New York: Cambridge University Press, 2011): 301-20; Cooper, "Social Rights."

27. International Labour Office, African Labour Survey (Geneva: ILO, 1958).

28. Quoted in Andrew Burton, "Raw Youth, School-Leavers and the Emergence of Structural Unemployment in Late-Colonial Urban Tanganyika," Journal of African History 47, no. 3 (2006): 372-73.

29. Iliffe, The African Poor, 171.

3o. Ibid., 6.

31. The Labor Department in Tanganyika is a good example for how the problem of unemployment was downplayed by officials. In order to meet the protests of African trade unionists about growing unemployment in the country's urban centers, a government official suggested: "I can't help feeling it's a problem on which we ought to be better informed, if only to show that we know what we are talking about if we say the problem is not serious." Quoted in Burton, "Raw Youth," 375. 
32. See Omar Guèye, Sénégal: histoire du mouvement syndical-la marche vers le Code du Travail (Paris: L'Harmattan, 2011); Cooper, Decolonization, chap. 7.

33. ILO, African Labour Survey, 404.

34. On gendered images of youth, see Andrew Burton and Helène Charton-Bigot, eds, Generations Past: Youth in East African History (Athens: Ohio University Press, 2010). For by now classic studies on the economic roles of women in colonial urban Africa, see Claire Robertson, Sharing the Same Bowl: A Socioeconomic History of Women and Class in Accra (Bloomington: Indiana University Press, 1984); Luise White, The Comforts of Home: Prostitution in Colonial Nairobi (Chicago: University of Chicago Press, 1990).

35. Cooper, Decolonization, 305-20. By contrast, the British subcommittee on wage fixing and family responsibilities rejected the concept of family allowances in 1953, not the least on political grounds. It argued that in "British Colonial territories the amount of any family allowance would be likely to be a greater proportion of a wage-earner's total income than in this country, and therefore, if family allowances were introduced, government would have a say in fixing a significant percentage of a man's total income. The workers could then reasonably conclude that their interests could be better advanced by political agitation than by action in the industrial field" (quoted ibid., 331).

36. Lisa Lindsay, Working with Gender: Men, Women, and Wage Labor in Southwest Nigeria (Portsmouth: Heinemann, 2003), shows this with the example of Nigerian railwaymen; see also Cooper, "African Labor History," 113.

37. Cooper, Decolonization.

38. Frederick Cooper, Africa since 1940: The Past of the Present (Cambridge: Cambridge University Press, 2002); Paul Nugent, Africa since Independence: A Comparative History (Houndsmills, U.K.: Palgrave MacMillan, 2004).

39. See Bill Freund, "Labor and Labor History in Africa: A Review of the Literature," African Studies Review 27 (1984): 1-58.

40. For statistical data, see John Sender and Sheila Smith, The Development of Capitalism in Africa (London and New York: Methuen, 1986). Their claim that "by the end of the colonial period, capitalist labor markets had become predominant, and that a working class had emerged as a major social and political force" (129) seems difficult to sustain. For the development in South Africa after the end of Apartheid, see Franco Barchiesi, "Wage Labor and Social Citizenship in Post-Apartheid South Africa," Journal of Asian and African Studies 42, no. 1 (2007): 39-72; and Scully, this volume.

41. James Ferguson, Expectations of Modernity: Myths and Meanings of Urban Life in the Zambian Copperbelt (Berkeley: University of California Press, 1999); Alastair Fraser and Miles Larmer, eds., Zambia, Mining, and Neoliberalism: Boom and Bust in the Globalized Copperbelt (New York: Palgrave Macmillan, 2010); Jonas Kreienbaum, "Der verspätete Schock-Sambia und die erste Ölkrise 1973/74," Geschichte und Gesellschaft 43, no. 4 (2017): 612-33.

42. For the South African context, see, for example, Franco Barchiesi, Precarious Liberation: Workers, the State, and Contested Social Citizenship in Postapartheid South Africa (Albany: State University of New York Press, 2011). Among the fast-growing literature on other parts of Africa, see Aili Mari Tripp, Changing the Rules: The Politics of Liberalization and the Urban Informal Economy in Tanzania (Berkeley: University of California Press, 1997); Dmitri van den Bersselaar, "Old Timers Who Still Keep Going: Retirement in Ghana," Österreichische Zeitschrift für Geschichtswissenschaften 22, no. 3 (2011): 136-52; also James Ferguson, Give a Man a Fish: Reflections on the New Politics of Distribution (Durham, NC: Duke University Press, 2015), 52.

43. Christian Nsiah and Bichaka Fayiassa, "Remittances to Africa and Economics," The Oxford Handbook of Africa and Economics, vol. 2: Policies and Practices, ed. Celestin Monga and Justin Yifu Lin (Oxford: Oxford University Press, 2015): 711-26.

44. Keith Hart, "Informal Income Opportunities and Urban Employment in Ghana," Journal of Modern African Studies 11, no. 1 (1973): 61-89; Cooper, "African Labor History." 
45. Kate Meagher, "The Scramble for Africans: Demography, Globalization and Africa's Informal Labor Markets," Journal of Development Studies 52 (2016): 485.

46. Franco Barchiesi, "Casual Labor and Informal Economy," Sociology of Work: An Encyclopedia, vol. 1, ed. Vicki Smith (Thousand Oaks, CA: Sage, 2013), 74-78; Ferguson, Give a Man a Fish. A good summary of the literature is offered by Kate Meagher, Identity Economics: Social Networks and the Informal Economy in Nigeria (Woodbridge, England: James Currey, 2010): 11-16. The following paragraphs profited much from discussions with Ravi Ahuja (Göttingen).

47. Emily Lynn Osborn, "Work and Migration," The Oxford Handbook of Modern African History, eds. John Parker and Richard Reid (Oxford: Oxford University Press, 2013), 196. An illuminating case study for this context is found in Trevor H. J. Marchand, The Masons of Djenné (Bloomington: Indiana University Press, 2009).

48. Gracia Clark, Onions Are My Husband: Survival and Accumulation by West African Market Women (Chicago: University of Chicago Press, 1997).

49. Ferguson, Give a Man a Fish, 106.

50. Frederick Cooper, "From Enslavement to Precarity? The Labour Question in African History," in The Political Economy of Everyday Life in Africa: Beyond the Margins, ed. Wale Adebanwi (Woodbridge, England: James Currey, 2017), 139.

51. Franco Barchiesi, "Precarious and Informal Labour," in General Labour History of Africa, Stefano Bellucci \& Andreas Eckert, eds. (Woodbridge: Boydell \& Brewer/James Currey), 45-76.

52. Benedetta Rossi, "What 'Development' Does to Work," International Labor and Working-Class History 92 (2017): 7.

53. Daniel Maul, Human Rights, Development and Decolonization. The International Labour Organization, 1940-70 (Houndmills, U.K.: Palgrave Macmillan, 2012), 265. For a case study that emphasizes continuities of forced labor into the period of independence, see Romain Tiquet, Travail forcé et mobilisation de la main d’oeuvre au Sénégal, Années 1920s-196os (Rennes, France: Presses Universitaires de Rennes, 2019).

54. International Labour Organization (ILO), Regional Brief for Africa. 2017. Global Estimates of Modern Slavery and Child Labour, https://goo.gl/9MEqM7.

55. Cooper, "From Enslavement to Precarity?" 140.

56. For a useful account on this complex, see Peter Tinti and Tuesday Reitano, Migrant, Refugee, Smuggler, Saviour (London: Hurst, 2016). In a recent book, widely acclaimed by European politicians and heavily criticized by scholars (especially demographers), the journalist Stephen Smith (La Ruée vers l'Europe: Le jeune Afrique en route pour le Vieux Continent, Paris: Grasset, 2018) predicts a "stampede for Europe" and argues that the scale of migratory pressure from Africa will submit Europe to a trial without precedent.

57. Meagher, "Scramble for Africans," 487.

58. Breman and Van der Linden, "Informalizing the Economy."

59. Craig Phelan, "Trade Unions, Democratic Waves, and Structural Adjustment: The Case of Francophone West Africa," Labor History 52, no. 4 (2011): 461-81. 